\title{
Considering Sex as a Biological Variable Will Be Valuable for Neuroscience Research
}

\author{
Rebecca M. Shansky ${ }^{1}$ and $\mathbb{C}$ Catherine S. Woolley ${ }^{2}$ \\ 'Department of Psychology, Northeastern University, Boston, Massachusetts 02115, and ²Department of Neurobiology, Northwestern University, Evanston, \\ Illinois 60208
}

The recently implemented National Institutes of Health policy requiring that grant applicants consider sex as a biological variable in the design of basic and preclinical animal research studies has prompted considerable discussion within the neuroscience community. Here, we present reasons to be optimistic that this new policy will be valuable for neuroscience, and we suggest some ways for neuroscientists to think about incorporating sex as a variable in their research.

\section{Introduction}

As of January 25, 2016, applicants for National Institutes of Health (NIH) grants to study vertebrate animals are required to explain how their study design will account for Sex as a Biological Variable (SABV). In most cases, this means that proposed studies should include both males and females; single-sex studies require strong scientific justification. As explained in the relevant policy announcement (NOT-OD-15-102), the rationale for an SABV policy comes from the observation that "more often than not, basic and preclinical animal research has focused on male animals and cells," which "may obscure understanding of sex influences on health processes and outcomes."

Has most basic and preclinical research focused on males? Beery and Zucker (2011) analyzed research articles using nonhuman mammals published during 2009 in 10 fields of biology and found that research in males dominated in 8 of them. The greatest biases were in neuroscience and pharmacology, where the ratios were $\sim 5$ studies using exclusively males to every 1 study using exclusively females. Physiology was intermediate at 3.7:1, and the bias was in the opposite direction in immunology (1:2.2) and reproductive science (1:1.6). Although some studies have reported weaker sex bias (e.g., Flórez-Vargas et al., 2016), an analysis done by one of us (C.S.W.) supports the findings of Beery and Zucker for neuroscience. Of 1244 neuroscience-related research articles using rodents published in 5 journals (Nature, Science, Nature Neuroscience, Neuron, and the Journal of Neuroscience) from June 2011 through May 2012, we found that 32\% studied

\footnotetext{
Received April 27, 2016; revised Aug. 8, 2016; accepted Aug. 16, 2016.

This work was supported by National Institutes of Health Grant NS037324 to C.S.W., Grant MH095248 to C.S.W., and Grant MH0988006 to R.M.S.

The authors declare no competing financial interests.

Correspondence should be addressed to either of the following: Dr. Rebecca M. Shansky, Department of Psychology, 360 Huntington Avenue, 125 NI, Northeastern University, Boston, MA 02115, E-mail:r.shansky@neu.edu; or Dr. Catherine S. Woolley, Department of Neurobiology, 2205 Tech Drive, Northwestern University, Evanston, IL 60208. E-mail: cwoolley@northwestern.edu.

DOI:10.1523/JNEUROSCI.1390-16.2016

Copyright $\odot 2016$ the authors $\quad 0270-6474 / 16 / 3611817-06 \$ 15.00 / 0$
}

exclusively males, $\sim 7 \%$ studied exclusively females, and only $\sim 4 \%$ studied both sexes and stated whether there were any differences between them; the remainder of the studies either used both sexes without mentioning differences or the lack of them ( $\sim 29 \%$ ) or failed to note the sex of the animals studied ( $\sim 28 \%$ ). Beery and Zucker also quantified failure to report the sex of animals used to generate published results, which they found in $\sim 20 \%$ of neuroscience articles. Together, the study by Beery and Zucker, our own analyses, and similar findings by others (e.g., Mogil and Chanda, 2005; Yoon et al., 2014), indicate that sex bias in animal research, more often in favor of males, is real.

The next question is whether sex bias in animal research is an obstacle to the NIH mission, which is to "seek fundamental knowledge about the nature and behavior of living systems" and apply that knowledge to "enhance health, lengthen life, and reduce illness and disability." That is, does the fact that most basic research is conducted in males limit the ability of basic science to inform clinical studies and public health policies? And if so, will requiring both sexes in NIH-funded research relieve this limitation in a tangibly beneficial way? Opinions vary widely on these questions. Announcement that an SABV policy was on the horizon (Clayton and Collins, 2014) was accompanied by both optimistic (McCullough et al., 2014) and pessimistic (Fields, 2014) commentary about its potential benefits. Detractors have voiced concerns about the feasibility of implementing and adhering to the policy (outlined and addressed by Mogil, 2016; Maney, 2016), as well as skepticism that such a broad mandate will translate to improved health outcomes (Richardson et al., 2015). However, others have expressed support for the initiative, suggesting that addressing the imbalance in subject sex is not only long overdue from a public health standpoint (Cahill and Aswad, 2015) but is also an essential step toward understanding the brain at its most fundamental level (Klein et al., 2015; Mazure, 2016). We, too, are optimistic that SABV will benefit neuroscience at both the basic and translational levels. Our goals in this Dual Perspective are to explain why and to suggest some ways for neuroscientists to think about sex as a variable in their research. 


\section{Will SABV strengthen basic neuroscience research?}

Despite the relative infrequency of basic neuroscience studies that include both male and female subjects, the existence of sex differences in brain biochemistry, physiology, structure, and function is broadly accepted (Becker et al., 2005; McCarthy et al., 2012; Bangasser et al., 2016; Panzica and Melcangi, 2016; but see Joel et al., 2015). Indeed, implicit in a decision not to include both sexes in study design is often a concern that outcomes in males and females might be different, complicating interpretation and obscuring what is "really" true about the brain. In other words: let's figure out the fundamentals first (usually in males) and worry about sex differences later. This is, of course, a flawed rationale because an outcome in one sex cannot be more or less true than it is in the other, nor is one sex more important to study than the other. The benefit of SABV is that by including both sexes in research, we learn the answers to research questions in both sexes. If findings in one sex do not apply to the other, then it seems clear that sex should be considered when reporting results. Conversely, when there is no sex difference, it is equally important to indicate that results can be considered true for both sexes.

As several recent reviews suggest, incorporating both sexes can be done most simply with a "50/50" approach, in which males and females equally comprise each experimental group (McCarthy, 2015; Mogil, 2016). Although this approach may not be sufficiently powered to detect small sex effects, large effects should be evident. Researchers can then choose whether to explore the biological basis of sex differences in follow-up experiments. Importantly, the results of such studies will be datasets generated in, and therefore relevant to, both sexes.

One common question about SABV is: how important are gonadal hormones? Because most human patients suffering from a disease or disorder are gonadally intact, human disease conditions will typically be modeled most effectively using gonadally intact animals. Some researchers have expressed concerns that including both sexes will require increased sample sizes to accommodate variability among females due to hormonal fluctuations across the reproductive cycle. However, a recent metaanalysis of variability among male and female mice across almost 10,000 published measurements of behavioral, morphological, physiological, or molecular traits showed that variability was no greater in females than males for any endpoint; indeed, variability was greater in males for several measures (Prendergast et al., 2014). Similar meta-analyses in other species have come to the same conclusion (Mogil and Chandra, 2005; Itoh and Arnold, 2015; Becker et al., 2016). This does not mean that the estrous cycle has no effect on neural function or behavior; to the contrary, there is evidence for estrous effects on many processes, from hippocampal LTP (Warren et al., 1995; Good et al., 1999) to sensitivity to stress (Shansky et al., 2004). However, it does mean that there is little reason to expect that use of gonadally intact females will add variability to outcomes. Some sources of variability may be the same in males and females, and some may be distinct. As above, it is up to individual researchers to determine which sources of variation are of interest to their research program.

One way to think about circulating gonadal hormones (in both sexes) is simply to accept them as part of the complex physiological background of each animal. With this strategy, experimental design need not attempt to control, remove, or manipulate hormones, but focus instead on identifying effects that transcend the influence of hormones. For example, Gruene et al. (2015) recently identified an active conditioned fear response in rats ("darting") that occurred predominantly in females and was evident in all phases of their estrous cycle. Alternatively, if there is interest in determining whether a particular effect depends on circulating gonadal hormones, a design in which the gonads are removed (gonadectomy) may be used. This can identify sex differences that arise during development and that are independent of the postpubertal hormonal milieu. Some researchers, including one of us (C.S.W.), have taken this approach.

For example, Tabatadze et al. (2015) used gonadectomized adult rats to show a sex-specific response of hippocampal inhibitory synapses to inhibition of fatty acid amide hydrolase (FAAH), an enzyme that hydrolyzes endocannabinoids. Synaptic inhibition was suppressed by an FAAH inhibitor in females, with no effect of the same drug in males. Because endocannabinoids are involved in diverse aspects of brain function, including cognition, appetite, pain, and responses to stress, the enzymes that regulate their levels are promising targets for therapeutic development (Fowler, 2015). Indeed, FAAH inhibitors have been used in clinical trials. Recognition that FAAH inhibitors have different effects in the hippocampus of male and female rats suggests that these or other drugs that influence endocannabinoids could affect men and women differently.

Sex differences that are independent of circulating gonadal hormones have also been shown using prepubertal animals. One recent example comes from a study of the cerebellar nuclei $(\mathrm{CbN})$, which carry the output of the cerebellum. The firing rate of CbN neurons in weanling (P17-P24) mice previously was measured to be $\sim 90$ spikes/s in mixed-sex studies. However, when data from males and females were analyzed separately, Mercer et al. (2016) found that the average firing rate was $\sim 65$ spikes $/ \mathrm{s}$ in males, compared with $\sim 100$ spikes/s in females. The same study also showed sex differences in synaptic excitation and synaptic inhibition of $\mathrm{CbN}$ neurons, as well as sex-specific responses to mutation of the autism-linked Gabrb3 gene.

Examples such as these demonstrate that considering sex as a variable can reveal sometimes striking sex differences in commonly studied systems for which there is little reason, a priori, to suspect that males and females would differ. Others have found similarly robust sex differences in many other systems, from spinal mechanisms involved in chronic pain (Mogil, 2012; Sorge et al., 2015) to reward circuitry and addiction-related behaviors (Becker and Koob, 2016). As these studies demonstrate, identifying what is the same between males and females and what is different is essential to provide appropriate baselines for future basic studies, as well as to inform translational studies that are based on outcomes of basic research.

As more neuroscientists begin to incorporate sex as a variable in their research, it will be important to consider assumptions that underlie interpretation of some standard outcome measures, and to be aware that these assumptions may not apply equally to males and females. This is particularly true for behavioral studies. For example, sex differences in responses to stress may influence common tests of anxiety and aversive learning. As reviewed by Archer (1975), female rodents show greater exploration and ambulation in the open field test, faster latencies to emerge into novel environments, and faster acquisition of active avoidance learning. Additionally, female rats exhibit less freezing in contextual fear conditioning (Maren et al., 1994) and are resistant to learned helplessness in a shuttlebox test (Dalla et al., 2008). One interpretation of these differences is that female rodents are simply less anxious and fearful than males. However, another possibility is that females are more likely than males to exhibit active behaviors in response to novel or aversive situations. 
The findings of Gruene et al. (2015) noted above support this idea. The active fear response in females that emerged during fear conditioning corresponded with less freezing behavior, the standard measure of conditioned fear in rodents. Thus, results in females could have been interpreted as reflecting poorer learning or lower fear than in males, had the active responses not been recorded. This mirrors earlier evidence of sex differences in active behaviors. For example, Fernandes et al. (1999) used principal component analysis of behavior in the elevated plus maze, a commonly used test of anxiety-like behavior. These authors found that, in males, anxiety accounted for $75 \%$ of variance in elevated plus maze behavior, whereas in females, anxiety accounted for only $34 \%$ of variance; the principal component for females was activity, at $57 \%$. Together, these studies suggest the need to reevaluate some classic behavioral assays, which may require adaptation as incorporation of female subjects increases (Shansky, 2015). One successful example of this comes from Lukas and Neumann (2014), who recently modified a social defeat model to reveal sexually divergent functions of oxytocin and vasopressin.

\section{Will SABV lead to improved health outcomes in humans?}

One of the most widely cited reasons for studying sex differences in the brain is that many neurological and neuropsychiatric disorders vary by sex, in their incidence, age of onset, symptoms, and/or responses to treatment. Although a detailed catalog of such differences is beyond the scope of this perspective, it is important to recognize that sex bias in brain disorders is evident at all life stages, from childhood through old age. For example, autism spectrum disorders, which are most often diagnosed at $\sim 4$ years of age, are $>4$ times more common in boys than girls (Christensen et al., 2016). In contrast, women are more likely than men to develop major depressive disorder, post-traumatic stress disorder, and anxiety disorders (Breslau, 2009), a wide range of pain syndromes (Fillingim et al., 2009), and show faster progression of Alzheimer's disease (Tschanz et al., 2011). Other disorders show smaller sex differences in overall incidence but manifest differently in men and women. For example, schizophrenia has consistently been shown to develop at an earlier age in men than women (Häfner et al., 1993; Castle et al., 1998), and symptoms differ between the sexes (Abel et al., 2010).

Although sex differences in human brain disorders may be determined partly by social and cultural factors, a great deal of evidence suggests that differences in biological processes that underlie the disorders' etiologies and pathophysiologies also play a role. It follows, then, that comparing these processes in male and female animal models could lead to better interventions and therapeutics in both men and women. In addition, even illnesses that afflict men and women with equal prevalence, such as bipolar disorder, may differ between the sexes in underlying mechanisms and/or risk factors (Dao et al., 2010). As articulated previously by de Vries (2004), some sex differences in the brain may serve to compensate for other sex differences, making endpoint measures in males and females more similar, rather than more different. Put simply, differences between males and females at a mechanistic level may converge to similar physiological or behavioral outcomes. This possibility highlights the importance of asking whether the answers to "fundamental" neuroscience questions are the same in both sexes.

Skepticism about whether studying both sexes in model organisms will result in improved public health is often framed as a translational problem (Richardson et al., 2015). Essentially, this argument asserts that the many environmental influences unique to humans (e.g., gender-related sociocultural norms and experiences) that could lead to discrepancies in disease incidence or drug effects do not factor into sexually divergent outcomes in basic science research and that, therefore, studying sex differences in laboratory animals is unlikely to provide insight into male-female differences in people. Although we acknowledge that animals are imperfect models of human behavior or disease, research in animals is currently the best approach available for understanding how biological processes work, defining the consequences of disrupting those processes, and testing interventions aimed at rescuing disruptions. Thus, to the extent that animal research is useful to understand biological processes that underlie human disorders, basic science should seek to understand how sex influences these processes. Furthermore, the potential value of SABV goes beyond informing clinical areas in which men and women are known to differ. Its broader impact will be to ensure that knowledge gained from basic biomedical research is relevant to both sexes.

Although we believe that SABV will benefit translational research in neuroscience, we also caution against overinterpretation of neuroscience studies, particularly in predicting cause-and-effect relationships that have not been directly demonstrated. For example, it can be tempting to speculate about how sex differences observed at a cellular or molecular level could produce sex differences in behavior. However, the potential consequences of sex differences at a mechanistic level must be considered in the context of whole-animal physiology; specific molecular differences may not have a direct behavioral correlate (as noted above, such differences may actually converge to common outcomes in males and females) (de Vries, 2004). Conversely, some sex differences in behavior may not be due to sex differences in the brain itself, but rather, to differences in other aspects of physiology. One case of this is female rodents' greater sensitivity to the rapid antidepressant effects of ketamine (Carrier and Kabbaj, 2013; Franceschelli et al., 2015), which appears to be due, at least in part, to their enhanced metabolism of ketamine to the antidepressant metabolite $(2 R, 6 R)$-hydroxynorketamine (Zanos et al., 2016).

\section{Resources for implementing SABV in neuroscience}

Designing and interpreting experiments that include both males and females can seem daunting, especially for researchers who are not familiar with studying both sexes. However, taking advantage of a number of excellent reviews, guides, and perspective pieces written by experts in the field can help to ensure that addressing $\mathrm{SABV}$ results in informative datasets that use limited resources wisely.

First, Janine Clayton, Director of the NIH Office for Research of Women's Health and a principal leader of the SABV initiative, recently published a piece in The FASEB Journal (Clayton, 2016) that outlines the rationale and goals for SABV. As a follow-up, Tannenbaum et al. (2016) discuss the guidelines for peer reviewers evaluating whether SABV has been satisfactorily incorporated into NIH proposals. Becker and Koob (2016) outline a framework for thinking about different types of sex differences, particularly in the context of addiction, and Sanchis-Segura and Becker (2016) provide a detailed discussion of how sex differences arise during development. Margaret McCarthy has provided several useful resources, including a debunking of myths about sex differences in the brain and a "roadmap" for incorporating SABV (McCarthy 2015), a decision tree-style framework for interpreting sex differences (Joel and McCarthy 2016; see also McCarthy et al., 
2012), and a primer on the history of sex differences research (McCarthy, 2016). This latter piece appears in a recent themed issue of Philosophical Transactions of the Royal Society B, which collectively addresses many aspects of sex differences in the context of neuroscience. Within this issue, we also recommend Donna Maney's thoughtful discussion of common "perils and pitfalls" in reporting the results of sex differences research. This piece offers excellent advice on thinking through SABV in experimental design, data interpretation, and communication, particularly to avoid overinterpretation of sex differences in ways that can promote damaging cultural stereotypes (also see Eliot, 2011). Finally, an upcoming special issue of Journal of Neuroscience Research will provide a broad look at the current state of sex differences research.

In conclusion, there is already compelling evidence for sex differences in numerous areas of neuroscientific research, but our understanding of many aspects of neural function is still limited primarily to one sex. Adherence to SABV will likely reveal further surprising ways in which aspects of neural function differ between the sexes, as well as neurobiological mechanisms that are conserved across the sexes. Both outcomes will broaden our understanding of fundamental processes and may also critically inform efforts to translate basic research findings into new approaches to the diagnosis, treatment, and prevention of brain-related disorders. We encourage basic neuroscientists to view SABV not as a burden, but as an opportunity to more thoroughly and more accurately identify the key factors that influence brain function. The results will likely benefit both sexes.

\section{Response from Dual Perspectives Companion} Authors-Lise Eliot and Sarah S. Richardson

Sex is obviously important in biological research. In this Dual Perspective piece, as well as in their individual research programs, Shansky and Woolley have made vital contributions to understanding the role of sex and gonadal hormones in biological processes from the cellular to the behavioral level. Sex differences and the impact of sexrelated variables on physiology and behavior are crucial areas of study. This research has advanced dramatically in the last few decades and provided key insights into basic mechanisms of neuronal function and the biological basis of behavior (McCarthy, 2016).

However, the importance of sex difference research does not mean that every biologist should be forcibly recruited into this field. The nice thing about leaving the study of sex effects to experts like Shansky and Woolley is that they appreciate the nuance of sex-related findings, have the tools for dissecting them, and possess the experience to accurately interpret them. The same cannot be said for all other NIH-funded animal researchers, any more than every researcher has the knowledge and technical expertise to dissect the equally important effects of genetic background (strain), prenatal experience, aging, environmental enrichment, social housing, and many other key variables that affect physiology and behavior. Whatever they are studying, biomedical scientists should be free to choose the model animal that best suits their needs and to narrow down competing variables to focus on the specific aims of their research.

Like Shansky and Woolley, we regret the historical precedent (probably rooted in societal gender assumptions) that led to the bias toward male-based studies in many areas of animal research. We agree that animal researchers have overused males on the erroneous assumption that estrus effects make females unacceptably variable. Recent metaanalyses demonstrate that this is not the case (Prendergast et al., 2014; Becker et al., 2016), and as more researchers become aware of the utility of female animals, we are confident they will find ways to include them in their research.

But the argument that requiring sex comparisons in every strain of rat, mouse, and other laboratory animal will lead to advances in human medicine is currently unfounded. As we point out in our companion piece, even the FDA's change in recommended zolpidem dosing for women was not based on animal research, nor could it have been detected in animals due to species differences in pharmacokinetics and pharmacodynamics. Similarly, the finding, cited by Woolley and Shansky, of greater ketamine sensitivity in female mice (Carrier and Kabbaj, 2013) does not translate to humans, where ketamine appears to be a more effective antidepressant in men (Coyle and Laws, 2015). Certainly, sex differences in pharmacokinetics and pharmacodynamics are important in both medicine and preclinical research, but there is little evidence that such sex differences reliably carry over between species (Anderson 2005). As we hope to impress upon neuroscientists, this is because "sex" is not the simple binary variable that this mandate assumes. It is a complex phenotype subject to conditions that vary across species, developmental age, and environmental context.

\footnotetext{
References

Anderson GD (2005) Sex and racial differences in pharmacological response: where is the evidence? Pharmacogenetics, pharmacokinetics, and pharmacodynamics. J Womens Health (Larchmt) 14:19-29. CrossRef Medline

Becker JB, Prendergast BJ, Liang JW (2016) Female rats are not more variable than male rats: a meta-analysis of neuroscience studies. Biol Sex Differ 7:34. CrossRef Medline

Carrier N, Kabbaj M (2013) Sex differences in the antidepressant-like effects of ketamine. Neuropharmacology 70:27-34. CrossRef Medline

Coyle CM, Laws KR (2015) The use of ketamine as an antidepressant: a systematic review and meta-analysis. Hum Psychopharmacol 30:152-163. CrossRef Medline

McCarthy MM (2016) Multifaceted origins of sex differences in the brain. Philos Trans R Soc Lond B Biol Sci 371:20150106. CrossRef Medline

Prendergast BJ, Onishi KG, Zucker I (2014) Female mice liberated for inclusion in neuroscience and biomedical research. Neurosci Biobehav Rev 40:1-5. CrossRef Medline
}

\section{References}

Abel KM, Drake R, Goldstein JM (2010) Sex differences in schizophrenia. Int Rev Psychiatry 22:417-428. CrossRef Medline

Archer J (1975) Rodent sex differences in emotional and related behavior. Behav Biol 14:451-479. CrossRef Medline

Bangasser DA, Wiersielis KR, Khantsis S (2016) Sex differences in the locus 
coeruleus-norepinephrine system and its regulation by stress. Brain Res 1641:177-188. CrossRef Medline

Becker JB, Koob GF (2016) Sex differences in animal models: focus on addiction. Pharmacol Rev 68:242-263. CrossRef Medline

Becker JB, Arnold AP, Berkley KJ, Blaustein JD, Eckel LA, Hampson E, Herman JP, Marts S, Sadee W, Steiner M, Taylor J, Young E (2005) Strategies and methods for research on sex differences in brain and behavior. Endocrinology 146:1650-1673. CrossRef Medline

Becker JB, Prendergast BJ, Liang JW (2016) Female rats are not more variable than male rats: a meta-analysis of neuroscience studies. Biol Sex Differ 7:34. CrossRef Medline

Beery AK, Zucker I (2011) Sex bias in neuroscience and biomedical research. Neurosci Biobehav Rev 35:565-572. CrossRef Medline

Breslau N (2009) The epidemiology of trauma, PTSD, and other posttrauma disorders. Trauma Violence Abuse 10:198-210. CrossRef Medline

Cahill L, Aswad D (2015) Sex influences on the brain: an issue whose time has come. Neuron 88:1084-1085. CrossRef Medline

Carrier N, Kabbaj M (2013) Sex differences in the antidepressant-like effects of ketamine. Neuropharmacology 70:27-34. CrossRef Medline

Castle D, Sham P, Murray R (1998) Differences in distribution of ages of onset in males and females with schizophrenia. Schizophr Res 33:179183. CrossRef Medline

Christensen DL, Baio J, Van Naarden Braun K, Bilder D, Charles J, Constantino JN, Daniels J, Durkin MS, Fitzgerald RT, Kurzius-Spencer M, Lee LC, Pettygrove S, Robinson C, Schulz E, Wells C, Wingate MS, Zahorodny W, Yeargin-Allsopp M (2016) Prevalence and characteristics of autism spectrum disorder among children aged 8 years: autism and developmental disabilities monitoring network, 11 Sites, United States, 2012. MMWR Surveill Summ 65:1-23. CrossRef Medline

Clayton JA (2016) Studying both sexes: a guiding principle for biomedicine. FASEB J 30:519-524. CrossRef Medline

Clayton JA, Collins FS (2014) Policy: NIH to balance sex in cell and animal studies. Nature 509:282-283. CrossRef Medline

Dalla C, Antoniou K, Kokras N, Drossopoulou G, Papathanasiou G, Bekris S, Daskas S, Papadopoulou-Daifoti Z (2008) Sex differences in the effects of two stress paradigms on dopaminergic neurotransmission. Physiol Behav 93:595-605. CrossRef Medline

Dao DT, Mahon PB, Cai X, Kovacsics CE, Blackwell RA, Arad M, Shi J, Zandi PP, O’Donnell P, Knowles JA, Weissman MM, Coryell W, Scheftner WA, Lawson WB, Levinson DF, Thompson SM, Potash JB, Gould TD (2010) Mood disorder susceptibility gene CACNA1C modifies mood-related behaviors in mice and interacts with sex to influence behavior in mice and diagnosis in humans. Biol Psychiatry 68:801-810. CrossRef Medline

de Vries GJ (2004) Minireview. Sex differences in adult and developing brains: compensation, compensation, compensation. Endocrinology 145: 1063-1068. CrossRef Medline

Eliot L (2011) The trouble with sex differences. Neuron 72:895-898. CrossRef Medline

Fernandes C, González MI, Wilson CA, File SE (1999) Factor analysis shows that female rat behaviour is characterized primarily by activity, male rats are driven by sex and anxiety. Pharmacol Biochem Behav 64:731-738. CrossRef Medline

Fields RD (2014) NIH policy: mandate goes too far. Nature 510:340. CrossRef Medline

Fillingim RB, King CD, Ribeiro-Dasilva MC, Rahim-Williams B, Riley JL 3rd (2009) Sex, gender, and pain: a review of recent clinical and experimental findings. J Pain 10:447-485. CrossRef Medline

Flórez-Vargas O, Brass A, Karystianis G, Bramhall M, Stevens R, Cruickshank S, Nenadic G (2016) Bias in the reporting of sex and age in biomedical research on mouse models. Elife 5:e13615. CrossRef Medline

Fowler CJ (2015) The potential of inhibitors of endocannabinoid metabolism as anxiolytic and antidepressive drugs: a practical view. Eur Neuropsychopharmacol 25:749-762. CrossRef Medline

Franceschelli A, Sens J, Herchick S, Thelen C, Pitychoutis PM (2015) Sex differences in the rapid and the sustained antidepressant-like effects of ketamine in stress-naive and "depressed" mice exposed to chronic mild stress. Neuroscience 290:49-60. CrossRef Medline

Good M, Day M, Muir JL (1999) Cyclical changes in endogenous levels of oestrogen modulate the induction of LTD and LTP in the hippocampal CA1 region. Eur J Neurosci 11:4476-4480. CrossRef Medline

Gruene TM, Flick K, Stefano A, Shea SD, Shansky RM (2015) Sexually di- vergent expression of active and passive conditioned fear responses in rats. Elife 4:e11352. CrossRef Medline

Häfner H, Riecher-Rössler A, An Der Heiden W, Maurer K, Fätkenheuer B, Löffler W (1993) Generating and testing a causal explanation of the gender difference in age at first onset of schizophrenia. Psychol Med 23:925940. CrossRef Medline

Itoh Y, Arnold AP (2015) Are females more variable than males in gene expression? Meta-analysis of microarray datasets. Biol Sex Differ 6:18. CrossRef Medline

Joel D, McCarthy MM (2016) Incorporating sex as a biological variable in neuropsychiatric research: where are we now and where should we be? Neuropsychopharmacology. Advance online publication. Retrieved June 22, 2016. CrossRef Medline

Joel D, Berman Z, Tavor I, Wexler N, Gaber O, Stein Y, Shefi N, Pool J, Urchs S, Margulies DS, Liem F, Hänggi J, Jäncke L, Assaf Y (2015) Sex beyond the genitalia: the human brain mosaic. Proc Natl Acad Sci U S A 112: 15468-15473. CrossRef Medline

Klein SL, Schiebinger L, Stefanick ML, Cahill L, Danska J, de Vries GJ, Kibbe MR, McCarthy MM, Mogil JS, Woodruff TK, Zucker I (2015) Opinion: Sex inclusion in basic research drives discovery. Proc Natl Acad Sci U S A 112:5257-5258. CrossRef Medline

Lukas M, Neumann ID (2014) Social preference and maternal defeatinduced social avoidance in virgin female rats: sex differences in involvement of brain oxytocin and vasopressin. J Neurosci Methods 234:101-107. CrossRef Medline

Maney DL (2016) Perils and pitfalls of reporting sex differences. Philos Trans R Soc Lond B Biol Sci 371:20150119. CrossRef Medline

Maren S, De Oca B, Fanselow MS (1994) Sex differences in hippocampal long-term potentiation (LTP) and Pavlovian fear conditioning in rats: positive correlation between LTP and contextual learning. Brain Res 661: 25-34. CrossRef Medline

Mazure CM (2016) Our evolving science: studying the influence of sex in preclinical research. Biol Sex Differ 7:15. CrossRef Medline

McCarthy MM (2015) Incorporating sex as a variable in preclinical neuropsychiatric research. Schizophr Bull 41:1016-1020. CrossRef Medline

McCarthy MM (2016) Multifaceted origins of sex differences in the brain. Philos Trans R Soc Lond B Biol Sci 371:20150106. CrossRef Medline

McCarthy MM, Arnold AP, Ball GF, Blaustein JD, de Vries GJ (2012) Sex differences in the brain: the not so inconvenient truth. J Neurosci 32: 2241-2247. CrossRef Medline

McCullough LD, McCarthy MM, de Vries GJ (2014) NIH policy: status quo is also costly. Nature 510:340. CrossRef Medline

Mercer AA, Palarz KJ, Tabatadze N, Woolley CS, Raman IM (2016) Sex differences in cerebellar synaptic transmission and sex-specific responses to autism-linked Gabrb3 mutations in mice. Elife 5:e07596. CrossRef Medline

Mogil JS (2012) Sex differences in pain and pain inhibition: multiple explanations of a controversial phenomenon. Nat Rev Neurosci 13:859-866. CrossRef Medline

Mogil JS (2016) Perspective: equality need not be painful. Nature 535:S7. CrossRef Medline

Mogil JS, Chanda ML (2005) The case for the inclusion of female subjects in basic science studies of pain. Pain 117:1-5. CrossRef Medline

Panzica G, Melcangi RC (2016) Structural and molecular brain sexual differences: a tool to understand sex differences in health and disease. Neurosci Biobehav Rev 67:2-8. CrossRef Medline

Prendergast BJ, Onishi KG, Zucker I (2014) Female mice liberated for inclusion in neuroscience and biomedical research. Neurosci Biobehav Rev 40:1-5. CrossRef Medline

Richardson SS, Reiches M, Shattuck-Heidorn H, LaBonte ML, Consoli T (2015) Opinion: focus on preclinical sex differences will not address women's and men's health disparities. Proc Natl Acad Sci U S A 112: 13419-13420. CrossRef Medline

Sanchis-Segura C, Becker JB (2016) Why we should consider sex (and study sex differences) in addiction research. Addict Biol 21:995-1006. CrossRef Medline

Shansky RM (2015) Sex differences in PTSD resilience and susceptibility: challenges for animal models of fear learning. Neurobiol Stress 1:60-65. CrossRef Medline

Shansky RM, Glavis-Bloom C, Lerman D, McRae P, Benson C, Miller K, Cosand L, Horvath TL, Arnsten AF (2004) Estrogen mediates sex differ- 
ences in stress-induced prefrontal cortex dysfunction. Mol Psychiatry 9:531-538. CrossRef Medline

Sorge RE, Mapplebeck JC, Rosen S, Beggs S, Taves S, Alexander JK, Martin LJ, Austin JS, Sotocinal SG, Chen D, Yang M, Shi XQ, Huang H, Pillon NJ, Bilan PJ, Tu Y, Klip A, Ji RR, Zhang J, Salter MW, et al. (2015) Different immune cells mediate mechanical pain hypersensitivity in male and female mice. Nat Neurosci 18:1081-1083. CrossRef Medline

Tabatadze N, Huang G, May RM, Jain A, Woolley CS (2015) Sex differences in molecular signaling at inhibitory synapses in the hippocampus. J Neurosci 35:11252-11265. CrossRef Medline

Tannenbaum C, Schwarz JM, Clayton JA, de Vries GJ, Sullivan C (2016) Evaluating sex as a biological variable in preclinical research: the devil in the details. Biol Sex Differ 7:13. CrossRef Medline

Tschanz JT, Corcoran CD, Schwartz S, Treiber K, Green RC, Norton MC, Mielke MM, Piercy K, Steinberg M, Rabins PV, Leoutsakos JM, Welsh-
Bohmer KA, Breitner JC, Lyketsos CG (2011) Progression of cognitive, functional, and neuropsychiatric symptom domains in a population cohort with Alzheimer dementia: the Cache County Dementia Progression study. Am J Geriatr Psychiatry 19:532-542. CrossRef Medline

Warren SG, Humphreys AG, Juraska JM, Greenough WT (1995) LTP varies across the estrous cycle: enhanced synaptic plasticity in proestrus rats. Brain Res 703:26-30. CrossRef Medline

Yoon DY, Mansukhani NA, Stubbs VC, Helenowski IB, Woodruff TK, Kibbe MR (2014) Sex bias exists in basic science and translational surgical research. Surgery 156:508-516. CrossRef Medline

Zanos P, Moaddel R, Morris PJ, Georgiou P, Fischell J, Elmer GI, Alkondon M, Yuan P, Pribut HJ, Singh NS, Dossou KS, Fang Y, Huang XP, Mayo CL, Wainer IW, Albuquerque EX, Thompson SM, Thomas CJ, Zarate CA Jr, Gould TD (2016) NMDAR inhibition-independent antidepressant actions of ketamine metabolites. Nature 533:481-486. CrossRef Medline 